\title{
「学生とシニアの対話 in 関西」報告 \\ 京都大学, 大阪大学, 近畿大学, 神戸大学の熱気ある学生とシニアの対話 熱気ある対話は留親会でも続く
}

学生連絡会 羽倉尚人(武蔵工大)

2006年 3 月 11 日土曜日, 東大阪の近畿大学において, 「学生とシニアの対話 in 関西」が開催された。「学生とシ ニアの対話」は，2005年 7 月に武蔵工大において開催さ れて以来, 東工大 (2005年 8 月), 八戸工大 (2005年 9 月), 福井大 (2005年12月) と回を重ね, 今回で 5 回目となる。 今回の対話の最大の特徵は, 複数大学の学生が一堂に会 して開催された点である。京大, 阪大, 近大, 神戸大か ら50名の学生が集まった。広めの教室がいっぱいになる ほどの人数は，これまでで最大である。関西地区の学生 のエネルギー・原子力への関心の高さが, この人数に表 れていると思う。これまでの対話では, 学生がシニアに 圧倒されている感じがあったが, 今回はそれに負けない だけの熱気が学生側にもあると感じられた。

5 回目となった今回は, 対話の流れも固まりつつある ように思われた。はじめに開会セッションとして, 後藤 (学生連絡会 京大) から本会の趣旨とスケジュールにつ いての説明があった。続いて林氏(エネルギー問題に発 言する会, 幹事) より, エネルギー問題に発言する会の 紹介があり, シニアの皆様が一言ずつ自己紹介をされた (第 1 図)。

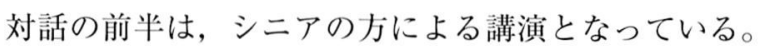
ここで, 近年のエネルギー問題について問題提起を行 い，後半の対話の種とすることを目的としている。これ までの対話では, シニアの方から 2,3 件の講演を頂い ていた。出身の異なるシニアの方から違う切り口で問題 提起をして頂こうと考えたためだ。しかし，対話後のア

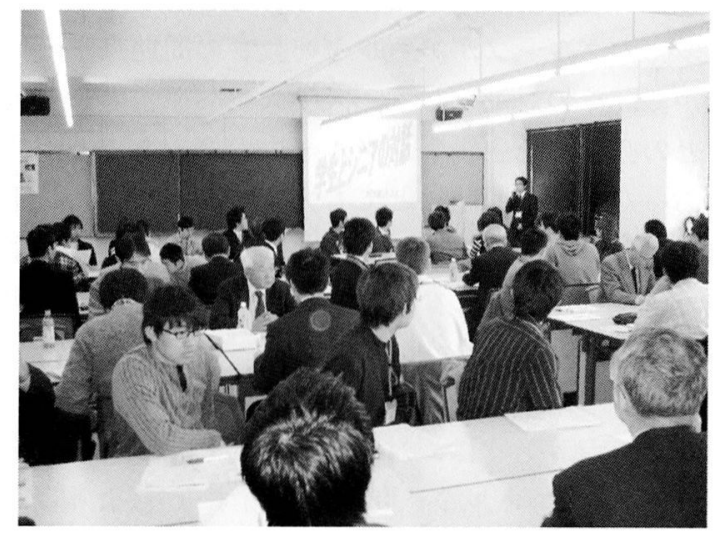

第 1 図 開会セッション
ンケートでは後半の対話の時間が短かったと指摘されて いた。そこで今回は講演を 1 件に絞り, その分の時間を 後半に回すように工夫された。

林氏より「エネルギー問題を原点から考えよう」と題さ れた講演を頂いた。ピークオイルの現実と, これからの エネルギーについて, EPR(発電システムのエネルギー 収支比率)やプラグイン・ハイブリッド車などのキー ワードを挙げながら詳しく解説された。30分という短い 時間であったものの，普段あまり聞きなれないテーマに 学生は真剣に耳を傾けていた。講演のあとの質疑応答 で, 参加している学生の意識の高さを感じることができ た。対話まで待ちきれないかのごとく，次々に手が挙が り，シニアの方々へ質問を投げかけていた。「原子力は 経済的であるというが, どれくらい安いのか」や，「鉄鋼 業で使用される石油の代替の可能性」,「ウランピークは どうなっているのか」どの質問が挙げられた。これに 対し，シニアは持参した資料を急遽示すなどして回答さ れた。この段階ですでに熱い議論が展開されたことに驚 くとともに, 後半のグループディスカッションにおいて さらに活発な議論が行われることが期待され，しばらく の休憩に入った。

対話の後半は, グループディスカッションだ。学生 6 名に対して, シニア 1 名から 2 名の 8 つのグループでそ れぞれ議論が行われた。参加した学生に対しては事前に アンケートを行っており, 学年や所属から, 進路やシニ アに聞きたいと思うこと, 関心のあるテーマなどが調査 されていた。グループ分けにおいては，これらの情報を 基に, 学年の近い者, 就職先の似ている者などが同じグ ループになるように工夫されていた。また，それぞれの グループの特色に合わせて, 最も議論が展開されやすい と思われるシニアの方を組み合わせるという点にも配虑 がなされていた。この甲斐あって，最後のまとめから， それぞれ満足のいく議論が行えた様子がうかがえた(第 2 図)。

グループディスカッションには80分の時間が設けられ ていた。これまでの対話の経験では, 前半はシニアの方 の話が中心になり, 学生はなかなか打ち解けて話し出せ ないという状況があり, 後半になってょうやく学生の意 見がいえるようになったかと思ったら, 時間切れになっ 


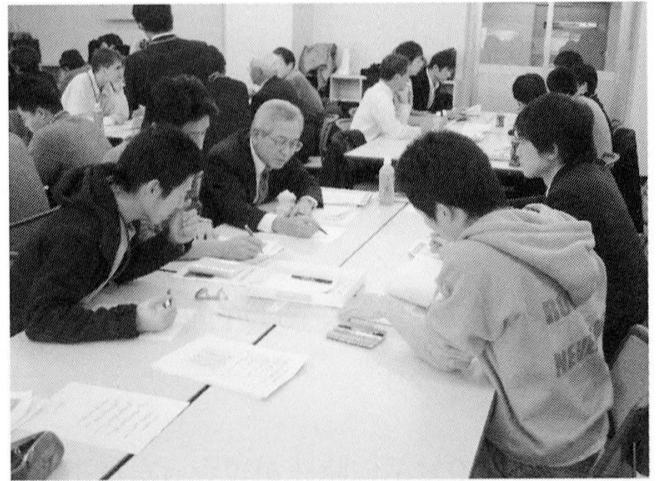

第 2 図 グループディスカッション

てしまうことが多いようであった。学生は普段，議論を するということに慣れていない。まして，シニアの方々 を前に自分の意見をうまく話すことができず，このよう な時間配分となってしまう。そして対話後のアンケート ではいつも後半の議論の時間が短かったという意見が大 势を占める。しかし今回は，先ほどの質疑応答の議論の 熱気そのままに対話に臨み，序盤から学生も積極的に意 見を述べているようであった。この違いはどこから来る のか。地域の問題なのか。グループ分けの工夫の問題な のか。

80分のディスカッションを終え，グループごとに発表 が行われた。グループディスカッションで話し合われた ことを一枚の画用紙にまとめ，それをスクリーンに映し 出しながら，グループの代表者が報告した。以下に各グ ループの発表をまとめる(第 3 図)。

A グループ： 主にエネルギー教育について話し合 われた。エネルギー問題に対して危機感が足りないこと が問題であるとした上で，考える力が重要であるとまと めた。

Bグループ： ピークオイルの認識をテーマに, 教 育, マスコミ, 日本のリードなどのキーワードを挙げ説 明した。マスコミというキーワードでは，日本における マスコミの䛊った報道が問題であると提起し, 日本の リードというキーワードでは, 日本にあるノウハウを途

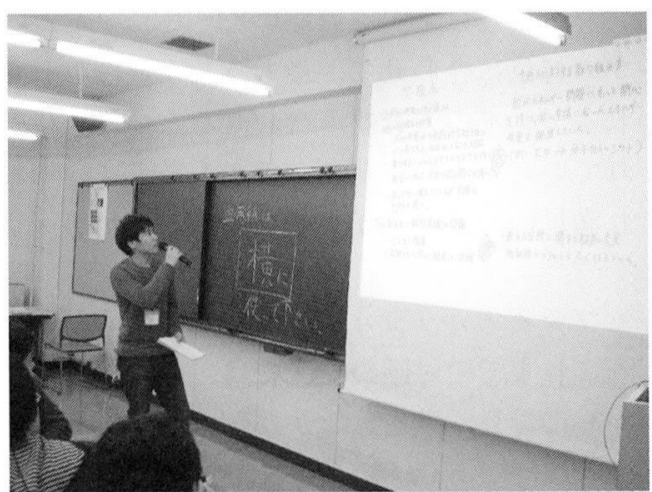

第 3 図 グループ発表
上国で活用すべきだと主張した。

Cグループ：一人前になるためには, と題して発表 した。キーワードに忍耐力, 社会に貢献, 創造力などを 挙げた。

D グループ：エネルギー教育の問題を採り上げた。 現状の問題点として, 地域による差を挙げた。例として, 福井出身の学生は小学生のときに原子力発電所の見学を した経験があるが, 大阪出身の学生にはそうした経験が ないことを挙げた。また, 専門家, 政府, マスコミ, 国 民の連携の必要性を訴えた。

Eグループ： エネルギー問題への理解の不足をテー マに話し合われた。この理解の不足は, 教育の不足から 来ているとした上で, 解決策として, 大学入試で原子力 を出題すべきだということを提案した。

F グループ： 原子力発電の伸び悩みとエネルギー問 題への意識の問題を採り上げた。後者においては, マス コミの対応や放射線についての理解を挙げ, 原子力教育 の充実と, 放射線利用のメリットをもっと伝えるべきで あるとまとめた。

$\mathrm{G}$ グループ： 原子力発電の割合を増やすためには, ということをテーマとした。キーワードとして, 消費者 の理解と, 政治のリーダーシップ, セーフティーネット を挙げ, 米国と日本の比較をした上で, セーフティーネッ トとして，原子力発電所を造る際に補助金を出すように するなどの措置について法整備などを含めて行うべきで あると主張した。

H グループ： 発電所の技術者として何ができるか， をテーマに話し合われた。マスコミとの関わりや入試へ の原子力の導入など社会に対する働きかけの重要性を述 ベ，そのためには，まずは発電所の安全を守ること，技 術者としての自らを鍛えることが重要であるとまとめ た。

発表を聞き，それぞれグループごとの特色のよく現れ たまとめになっていたと感じた。 H グループの結論とし て，自ら鍛えることが重要であるとまとめた点は，これ から技術者として原子力業界で活躍する学生がシニアの 方から頂いた重要なメッセージであると感じられる。ま た，多くのグループがエネルギー教育の問題点を指摘す るなかで, その対策として, 大学入試へ原子力を導入す ることの必要性を主張したグループがあったことが印象 的であった。教育問題はとても大きな問題である。重要 であることはわかっていても，どこから手を出せばよい か途方にくれる。そんな中で, この提案はひとつの鍵と なるのではないだろうか。

閉会セッションでは, 対話の総括として, シニアを代 表して中神氏(エネルギー問題に発言する会)よりコメン トを頂いた。極めて活発に議論が行われたことに充実し 
た時間が過ごせたという感想を頂いた。最後に, コーディ ネーターとして参加された天野氏 (日本原子力学会 企画 委員)より閉会の言葉を頂いた。今回対話に参加し, 学 生がシニアの方からたくさんの刺激を受けたであろうこ とは, 自己実現, 自己独立においてとても大切なことで あるとまとめられた。

本編終了後に行われた懇親会には, 対話の流れそのま まにほとんど学生が参加し, 引き続きシニアの皆様との 交流を楽しんだ。特に今回は, 複数の大学の学生が集まっ
たことから，学生間の交流も活発に行われた。縦のつな がりに加えて，横のつながりも深まり，今後ますますエ ネルギー・原子力の問題についての議論の輪が広がって いくことは，何より重要なことであると感じた。

参加されたシニアの皆様(これまでの原子力界をリー ドされた方々)

林 勉，金氏 顕，荒井利治，竹内哲夫，松永一郎， 石井 亨, 中神靖雄, 山崎吉秀の各氏

(2006年 3 月20日 記)

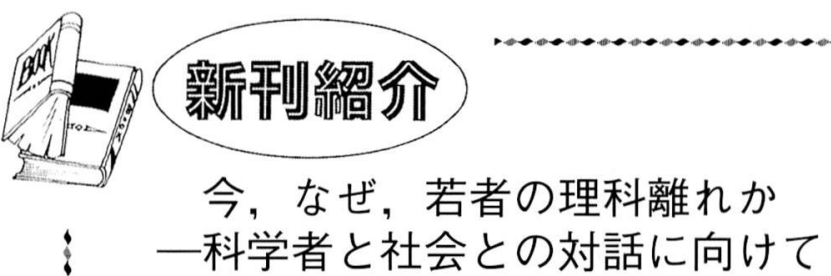

黑川 清, 北原和夫, 他著, A 5 判, 275 p. (2005), 学術会議叢書10, 日本学術協力財団.

(価格1,890円, 税込), ISBN 4939091198

この書名に引かれて本書をひもとくと，「すべての子ども は科学者である。という日本学術会議黒川 清会長の発刊の 辞がある。多くのものに「なぜ?」」を連発しながら成長する子 どもにとって,「理科」は面白く，好きな学科なのに，どうし てそれが理科離れを起こすのか, それは大人の理科離れ, 科 学離れを反映していると同会長は続ける。

理科離れはすでに各方面で叫ばれ，文部科学省も取り上げ てきた問題であるが，前期(第19期)の日本学術会議では直接 これに取り組むため，「若者の理科離れ問題特別委員会」(後 に「若者の科学力増進特別委員会」と改称)が設置された。本 特別委員会は積極的に調査と検討を重ね, 公開講演会やシン ポジウムを開催し，外国の現況も調査した。

本書はその活動報告であり，4 部から成る。第 1 部は講演 会「若者の科学力を増進する」で発表された 6 つの講演を載録 している。それぞれ含蓄があるが，白川英樹氏(筑波大名誉 教授)の「社会と理科離れ」, 高橋真理子氏 (朝日新開論説委員) の「科学者へ望むこと」など考えさせられる。

第 2 部は, パネル討諭「科学への理解と共感を深めるため に」での司会者と 9 名のパネリストの意見交換が丁寧に収録 されていて面白い。川合知二氏 (阪大教授)や黒田玲子氏 (東 大教授)が科学をわかり易く伝えることおよびインタープリ
夕ーの養成の必要性を訴え, 本間典 子氏 (東大助手)がその実践例として 大学院生による小学校でのリレー授 業を紹介している。

第 3 部は, 本特別委員会の委員 10 名が科学への夢を育み, 科学する 心を育てる」という課題でそれぞれ 意見を述べて扮り, 内容も充実して いる。著者名を省略して題目のみ列 記すると以下の通りである。「理科

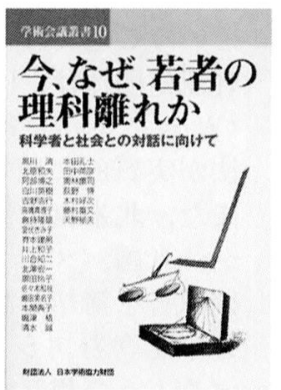
教育から見えてくる日本の初等・中等教育の問題点」,「ポテ ンシャルを探ること」,「若者の科学する心の坒失」,「国民一 人一人に科学する心を育てることから全てが始まる」,「情報 の時代と科学教育」, 「理系・文系科学の協力基盤」,「高等学 校・大学の化学実験の現状で科(化)学力は育つか」, 「工学屋 の見た“理科離れ”」，「若者の科学力一宮城県における小学校 理科教育調査からみた課題」,「砂上に楼閣を築くのか」。こ の中の「国民一人一人に…」で，本田孔士氏(大阪赤十字病院 院長) はわが国の科学ジャーナリズムの賓困さを厳しく断じ ている。また「砂上に楼閣を築くのか」は，有名な教育学者天 野郁夫氏 (東大名誉教授)の取りまとめ的議論である

最後に第 4 部は, 海外における理解増進と科学教育の展開 と題し，欧州 3 国との学術交流ならびにアジア諸国の初等・ 中等教育における理科・数学教育の現状について述べてい る。

書籍というよりも報告書であり，かつ理路整然とせずやや 寄せ集め的な感じがしないでもないが, 本学会でも理科離れ に関心を持つ会員も多かろうと察しここに紹介することに した。（前日本学術会議会員, 原子力安全システム研究所・木村逸郎) 